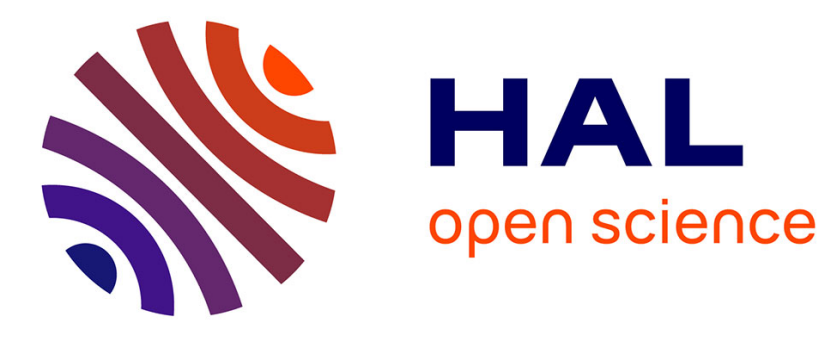

\title{
TILLING (Targeting Induced Local Lesions IN Genomes)
}

Richard Thompson, Christine Le Signor, Myriam Sanchez, Brigitte Darchy, Gregoire G. Aubert, Karine Gallardo, Christine Saffray, Marion Dalmais, Abdelhafid Bendahmane

\section{To cite this version:}

Richard Thompson, Christine Le Signor, Myriam Sanchez, Brigitte Darchy, Gregoire G. Aubert, et al.. TILLING (Targeting Induced Local Lesions IN Genomes). Scientific Workshop on the effects of biotic and abiotic stresses in legumes: the ABSTRESS and BIOTECSOJASUR projects, Mar 2016, Balcarce, Argentina. hal-02739092

\section{HAL Id: hal-02739092 https://hal.inrae.fr/hal-02739092}

Submitted on 2 Jun 2020

HAL is a multi-disciplinary open access archive for the deposit and dissemination of scientific research documents, whether they are published or not. The documents may come from teaching and research institutions in France or abroad, or from public or private research centers.
L'archive ouverte pluridisciplinaire HAL, est destinée au dépôt et à la diffusion de documents scientifiques de niveau recherche, publiés ou non, émanant des établissements d'enseignement et de recherche français ou étrangers, des laboratoires publics ou privés. 


\section{TILLING (Targeting Induced Local Lesions IN Genomes)}

Christine Le Signor, Myriam Sanchez, Brigitte Darchy, Grégoire Aubert, Karine Gallardo, Richard Thompson (INRA-UMR Agroécologie, Dijon)

Christine Saffray, Marion Dalmais, Abdelhafid Bendahmane (IPS Paris-Saclay) 


\section{TILLING: A method of producing and identifying mutations in}

any gene of interest

VMS-generated population of point mutants

- Make DNAs from each plant ( 4500), arrange in pools

- Screen for lines of interest by gene-specific detection

- Purify away from other mutations by back-crossing
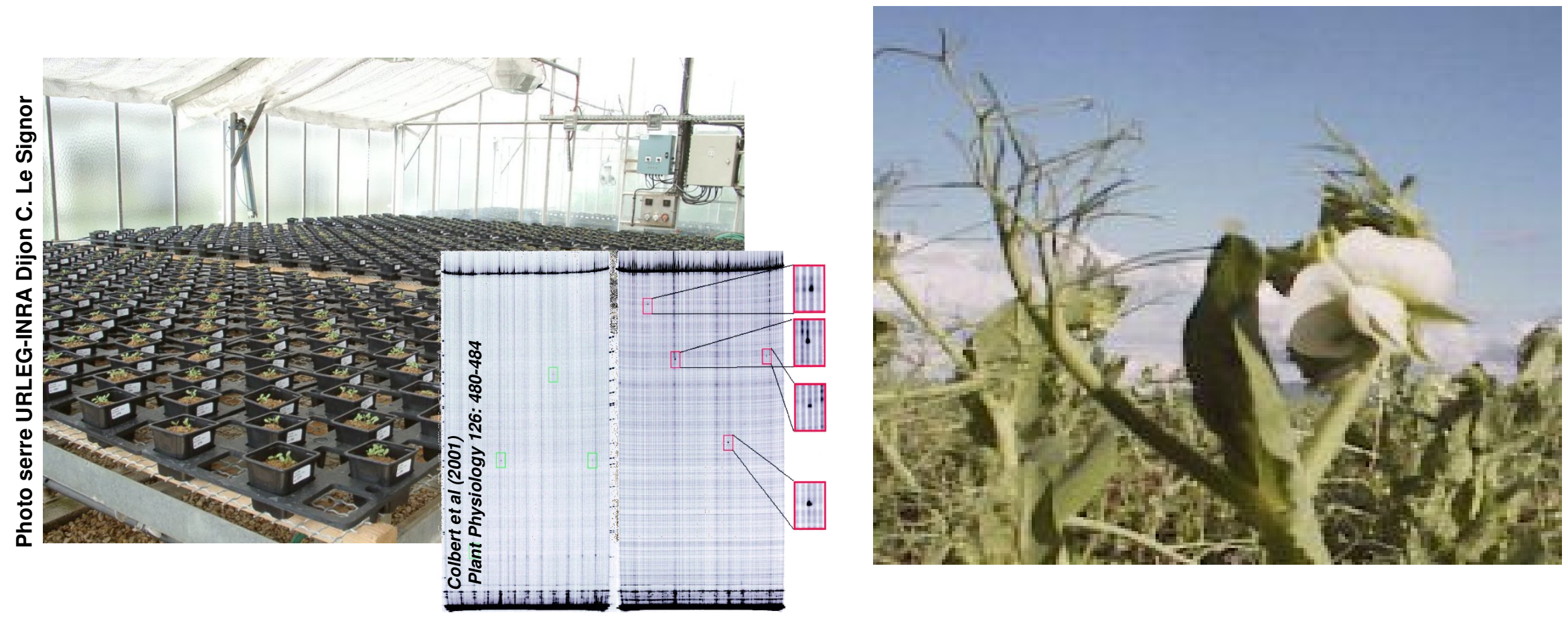


\section{TILLING}

Targeting Induced Local Lesions in Genomes

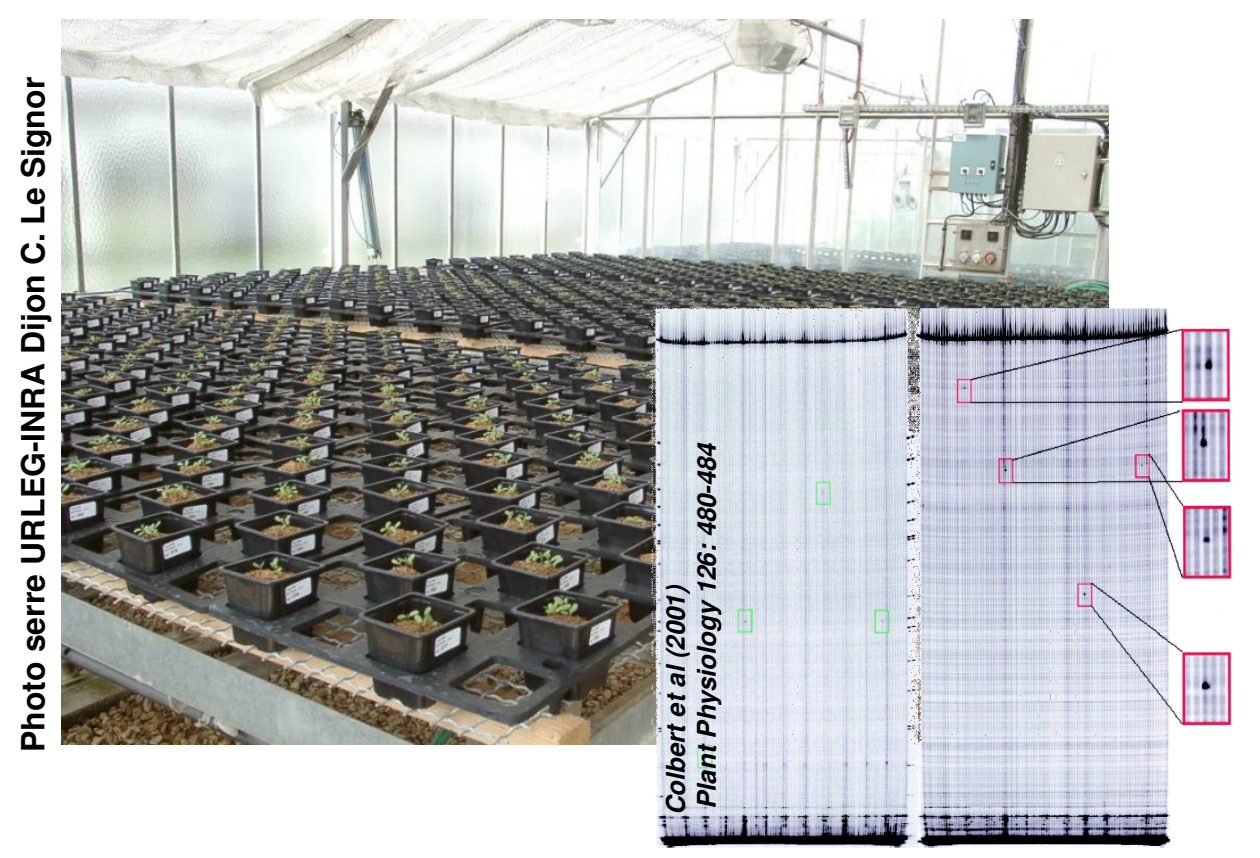

Method of producing and identifying

mutations in genes of

interest 


\section{Origin of TILLING}

Henikoff's lab

Basic Sciences Division, Fred Hutchinson Cancer Research Center, Seattle, USA.

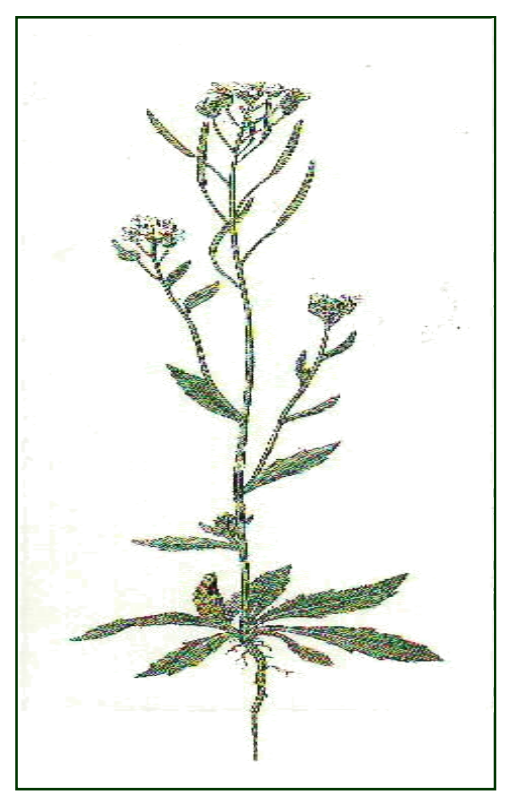

Arabidopsis (génome $125 \mathrm{Mb}$ )
Targeted screening for induced mutations.

McCallum et al.

Nat Biotechnol. 2000; 18(4): 455-7

High-throughput TILLING for functional genomics.

Till BJ et al.

Methods Mol Biol. 2003; 236:205-20. 


\section{Application of TILLING}

H. Cereals:

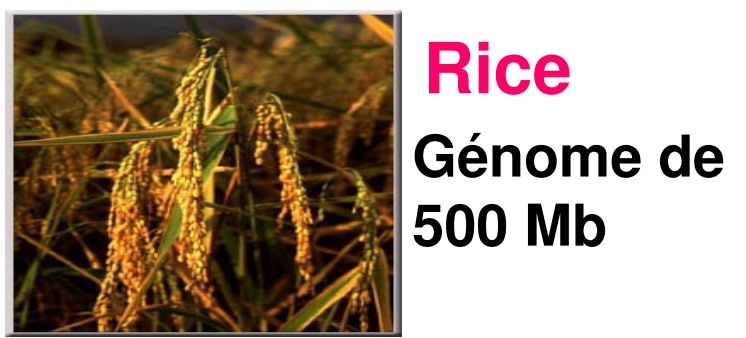

Crop Pathology and Genetics Research UC- Davis, USA

\section{Hegumes:}

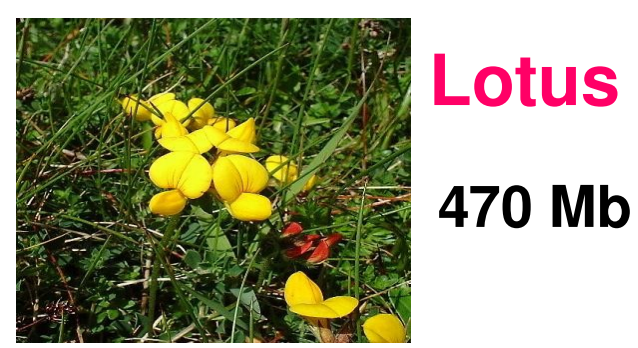

\footnotetext{
John Innes Centre Norwich, UK
}
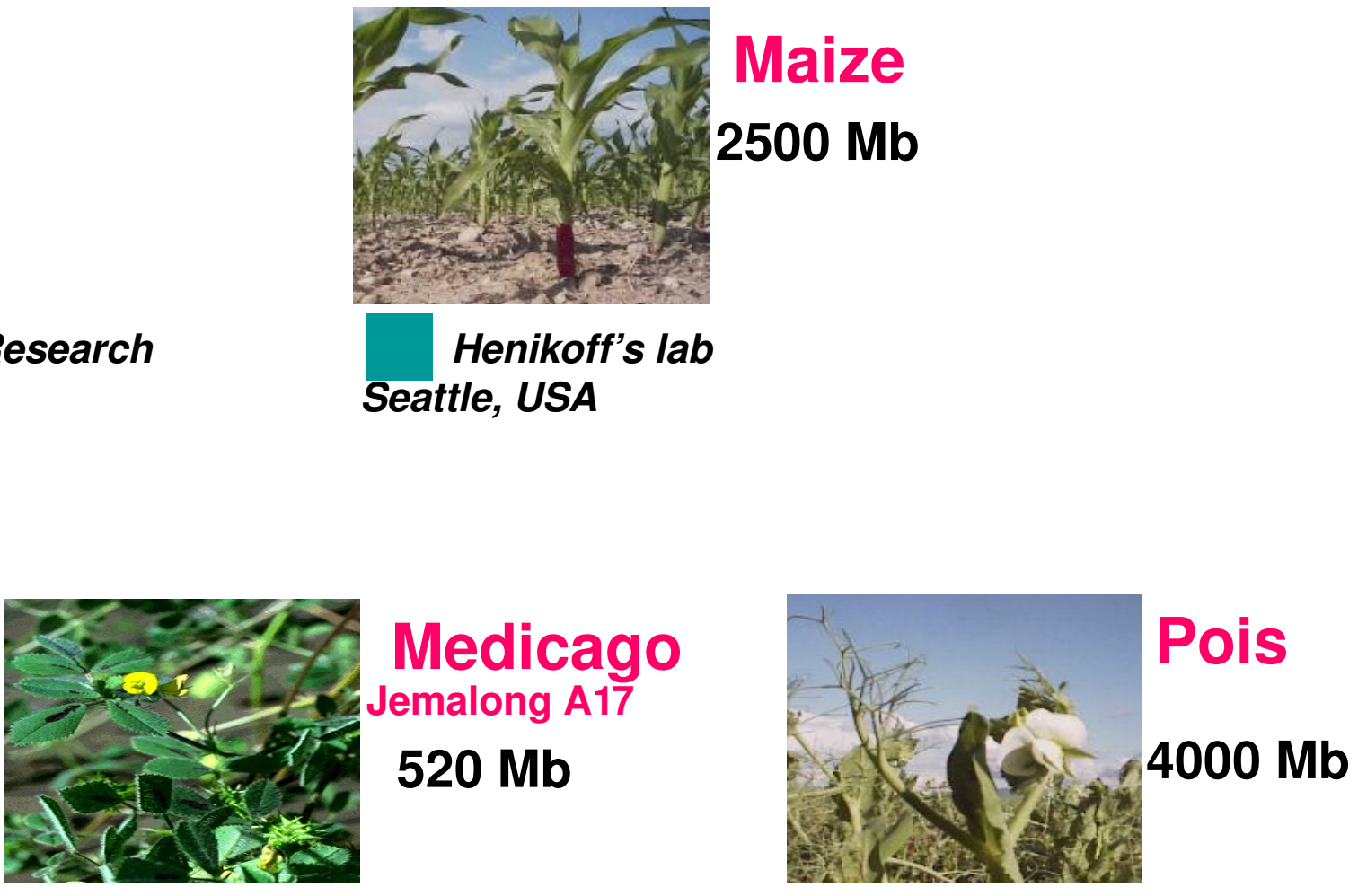

D. Cook's lab
UC Davis, USA
INRA Dijon
France

Medicago Jemalong A17 $520 \mathrm{Mb}$ INRA Dijon et URGV- INRA Evry France 


\section{Advantages of TILLING:}

A Applicable to all organisms (small or large genomes)

fi utilises a chemical mutagen which generates an allelic series of point mutations (mutation frequency 1 mutation/300 Kb).

Easily set up:

fi Rapid screening of a collection of mutagenized plants for the identification of point mutations in genes of interest 


\section{Steps in TILLING procedure}

6 Mutagenesis of genome using Ethyl Methane Sulfonate (EMS)

Production of an M2 population

Screening of the M2 population

Blsolation of lines bearing mutations in gene of interest and back-crossing to eliminate unwanted mutations 


\section{Assessment of mutation efficiency}

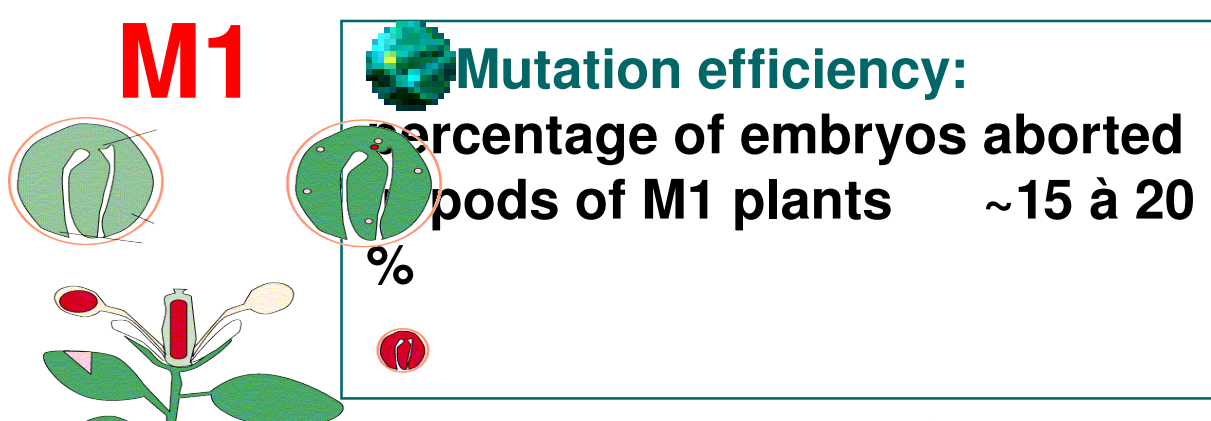

M2

Chimaera

M2 plant carrying one or several mutations in its genome

All the mutations are in the heterozygous state

$50 \%$ mutations heterozygote

$25 \%$ mutations homozygote

$25 \%$ homozygote wild-type

Recessive mutations no phenotype associated

$(99 \%)$ -

For recessive mutations: $25 \%$ of plants show phenotype

For dominant mutations: $75 \%$ of plants show phenotype 


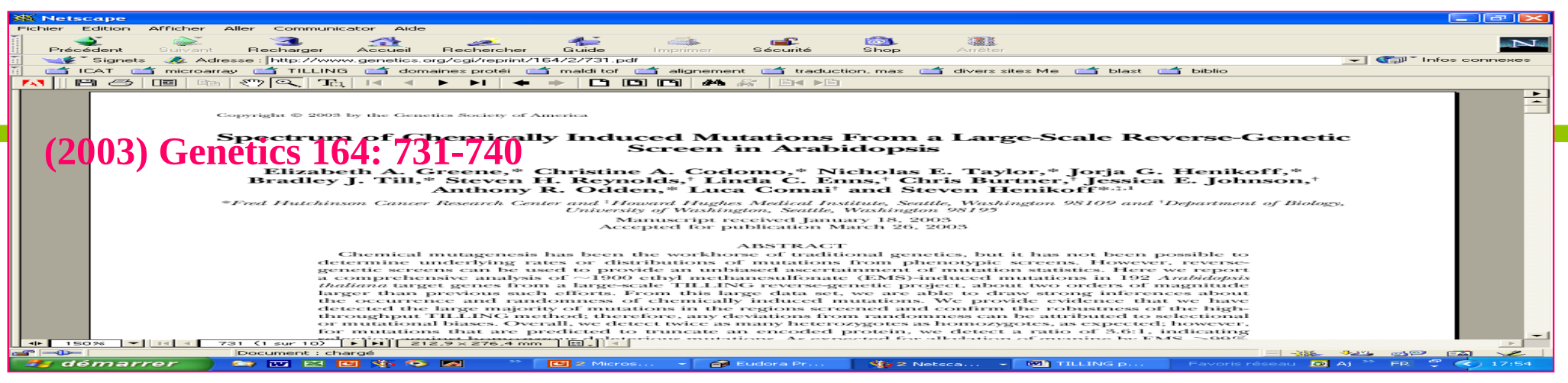

Mutation frequency: 1 mutation/300 kb (M2)

For a genome size similar to $M$. truncatula (500 Mb), the frequency would be 1500 mutations/plant M2)

Therefore backcrosses to WT line needed

Mutation distribution:

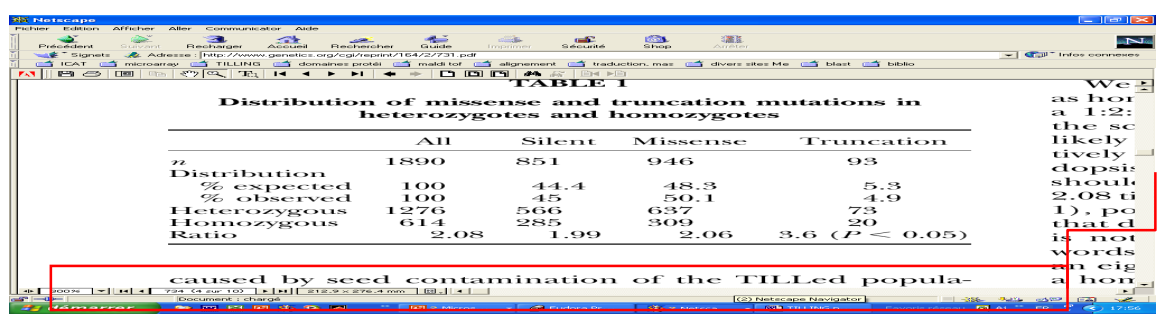

Silent mutations : $\quad 45 \%$ Missense mutations : $50 \%$ Stop codon Mutations: $4,9 \%$

Therefore need to isolate several mutants for each gene 


\section{Summary of TILLING method}

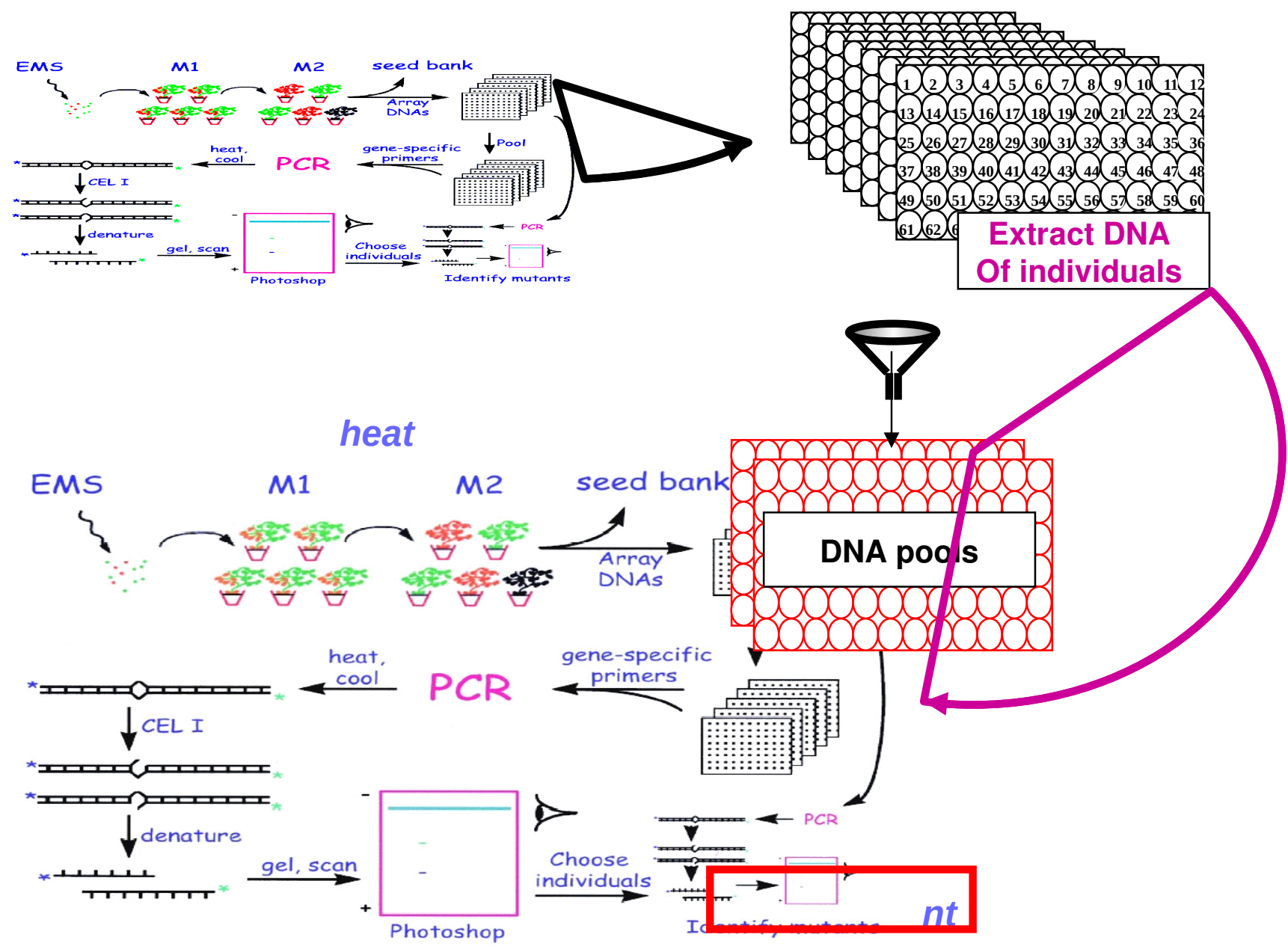

Screening carried out on DNA pools from 8-12 individuals on microtitre plates and subsequently on individual DNA samples. 


\section{(URGV Paris-Saclay)}
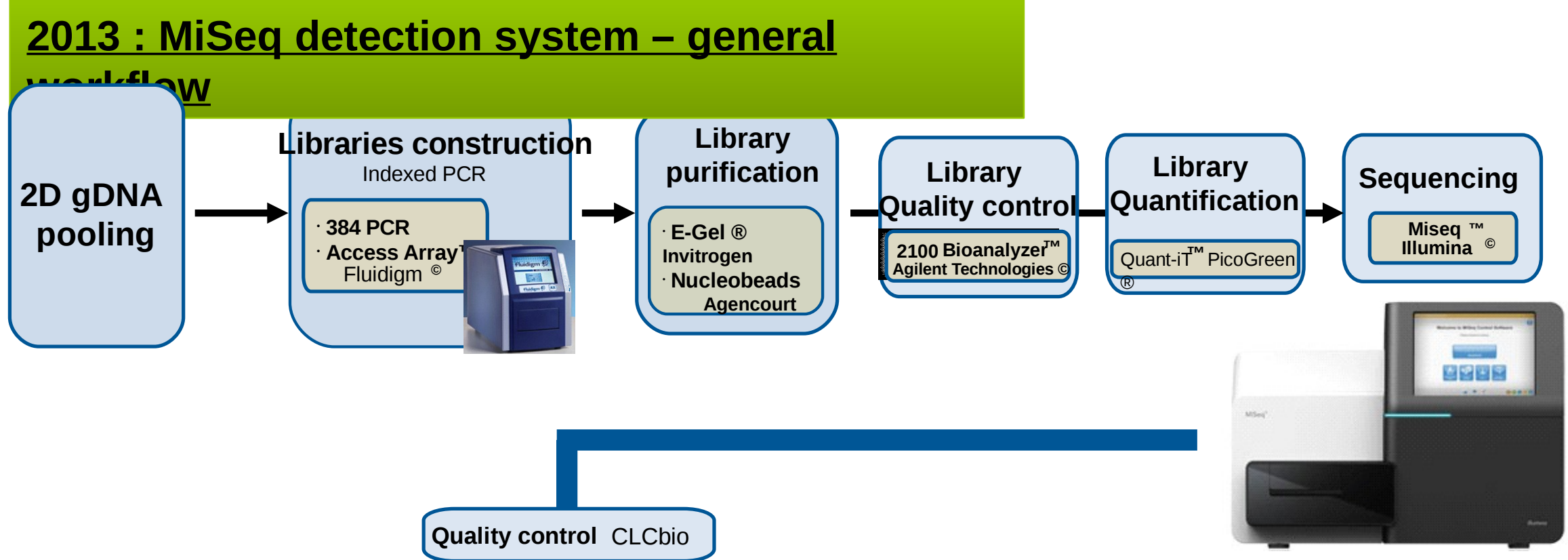

NGS data analysis : Alignment, SNP detection

Bowtie II

\section{Filter score}

Statistical analysis

Python, R, Unix

Results
Output in 1st pooling dimension

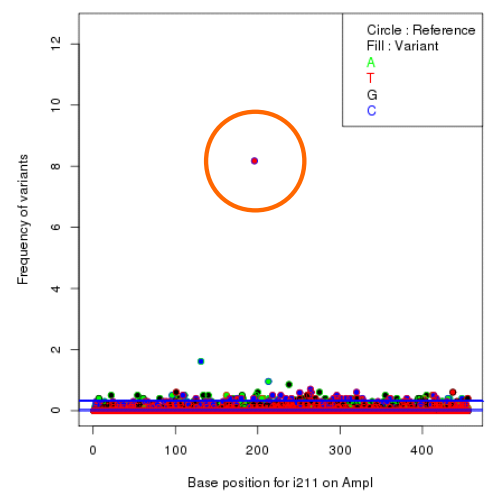

Output in 2nd pooling dimension

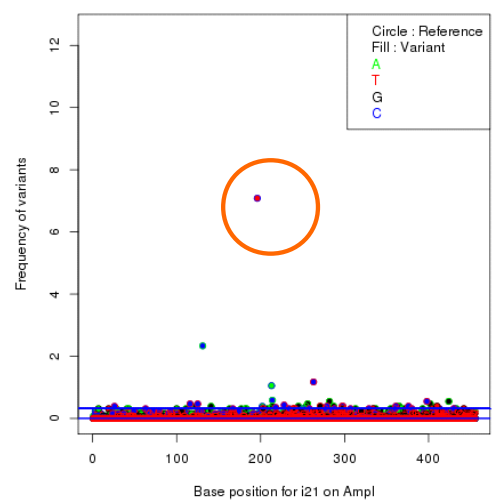




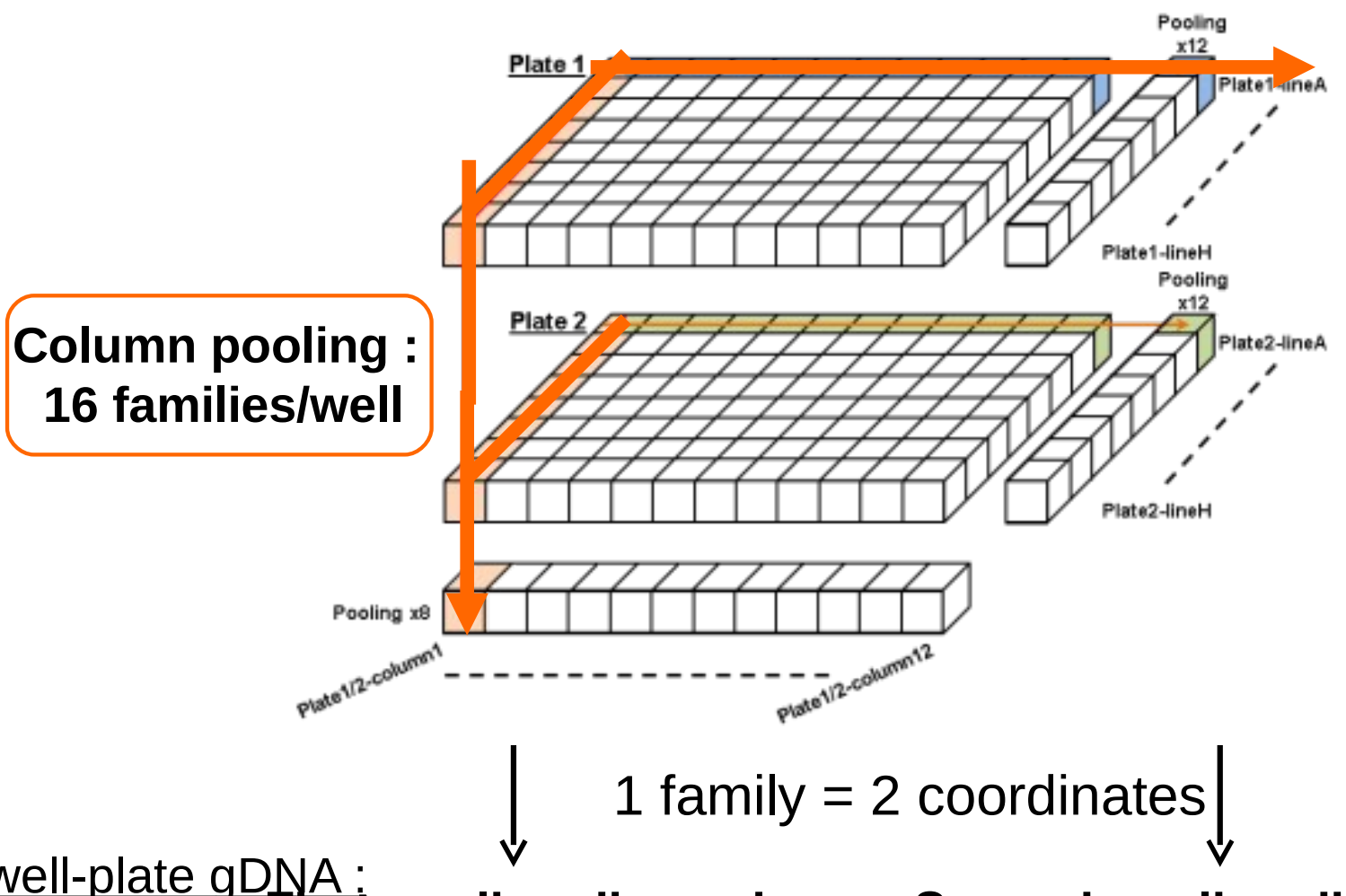

Row pooling :

12 families/well

384 well-plate gDNA

\section{First pooling dimension Second pooling dimension}
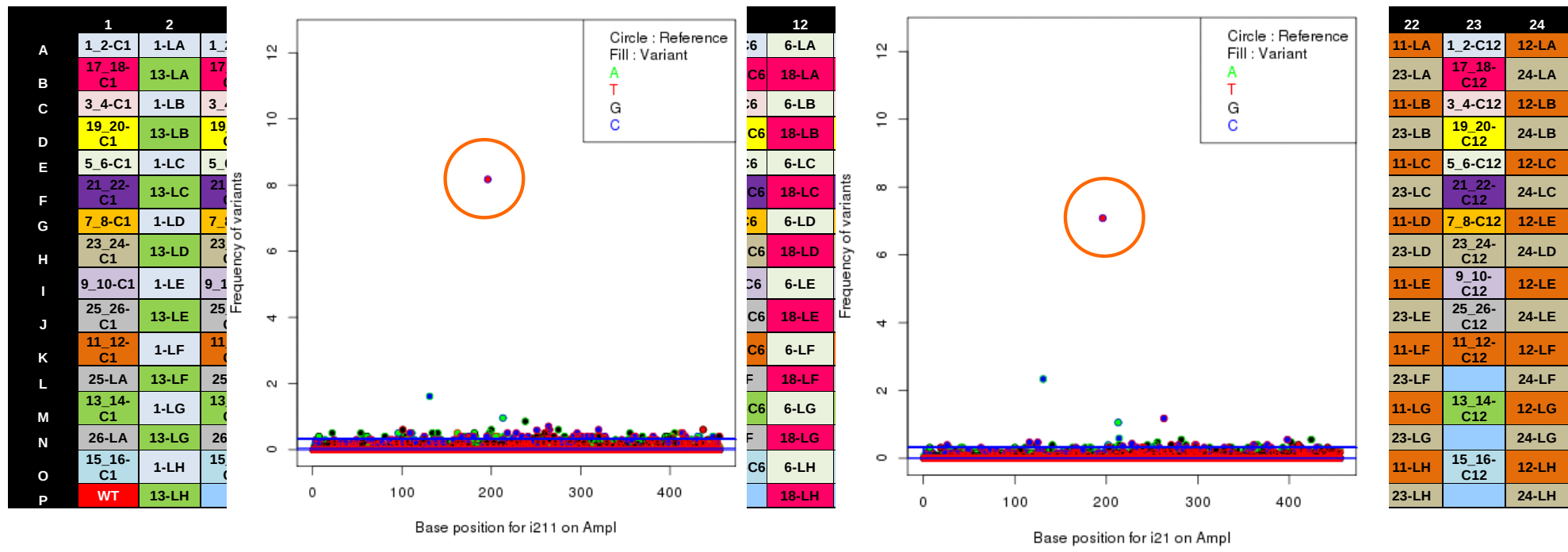
(URGV Paris-Saclay)

Cel1/Endo 1

NGS- MiSeq - Illumina
DNA pooling

Amplicon

Detection system

- Endonuclease digestion

- Detection of labelled DNA fragments on Li-Cor

- Sanger sequençing

\section{PCR 384}

1D

$1000 \mathrm{bp}$

1

1 month

1mutant/200 kb

5000

\begin{abstract}
Time/
experiment

Mutation

frequency

Families /

screen
\end{abstract}

2D (rows + columns pooling)

$500 \mathrm{bp}$

$500 \mathrm{bp}$

Pair-end sequencing

2 × 250bp $\square 2$ × 300bp

Sequence analysis

25

48

3 months

2-3 months

1mutant/130 kb

1 mutant/130 kb

384-well plate $=$ 2500 families 384-ivell plate $=$ 2500 families 


\section{Pea TILLING populations}

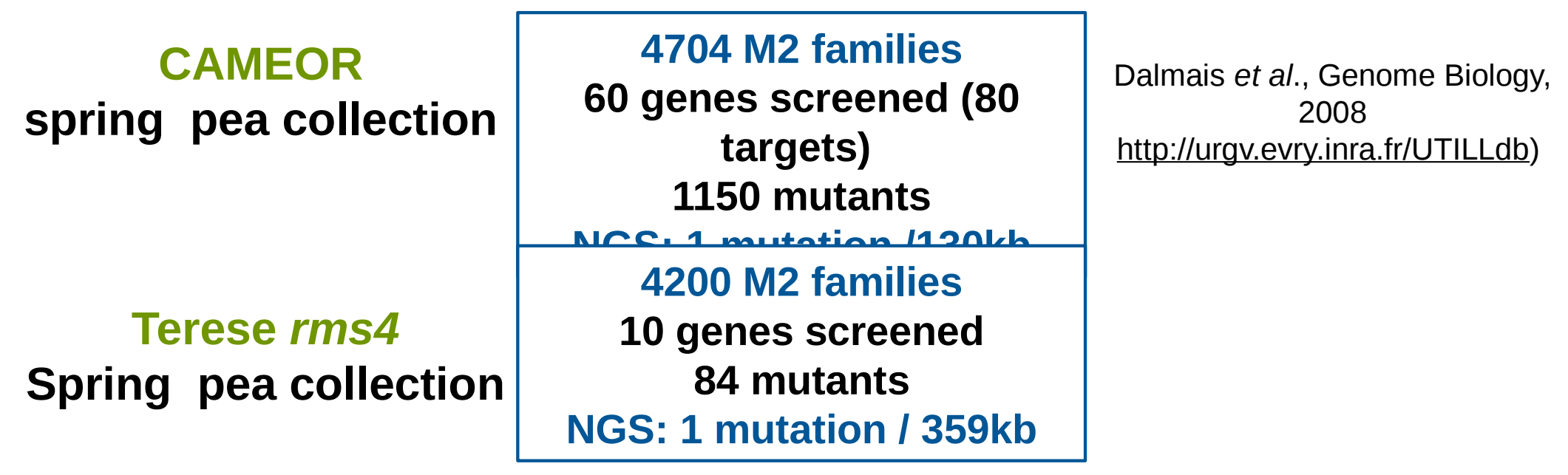

Hr Ps336/11 genotype PEAMUST Winter pea collection

2014 : DNA samples for 946 low-seeds M2 families

2015 : DNA samples for 960 high-seeds M2 families

\section{M2 families}

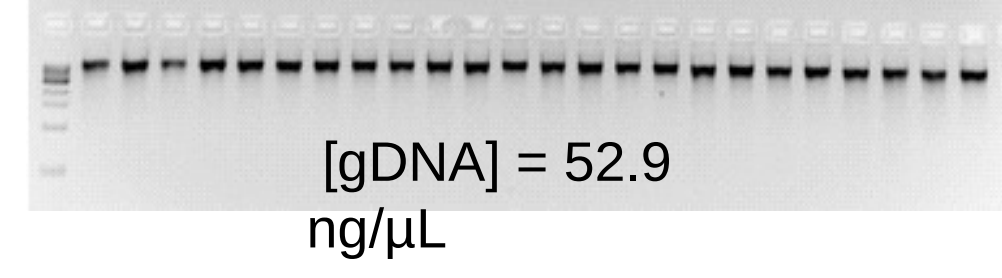

2016-2017 : end of population production 


\section{Variation in mutation frequency within treated seed lot}

$\rightarrow$ Comparison of mutation frequency in low- and high-yield families

Hr Ps336/11 genotype

PEAMUST Winter pea collection

$\longrightarrow 2014$ : DNA samples for 946 low-seeds M2 families (1-7

$\longrightarrow$ 2015: Diant) samples for 960

$\longrightarrow \quad \begin{aligned} & \text { 20eids: (D) ant) } \\ & \text { high-seeds M2 families (20-100 }\end{aligned}$ seeds/plant)

Mutation frequency $1 / 72 \mathrm{~kb}$

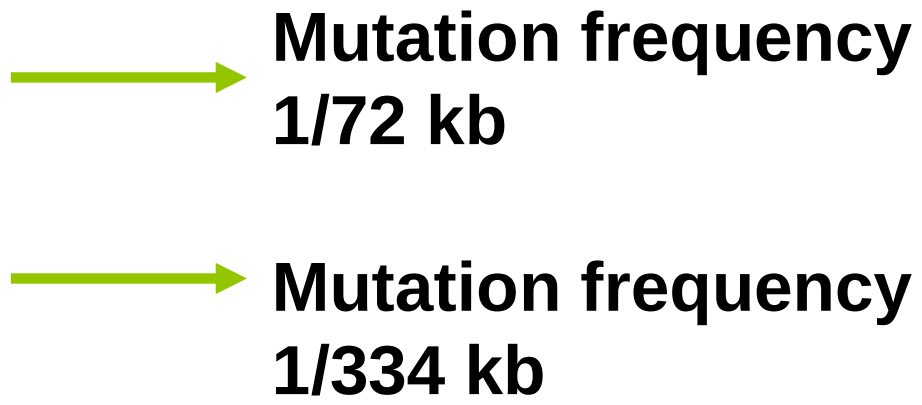

> Low-yield families had a mutation frequency 4-fold higher, but probability of losing the mutant allele also high $\rightarrow$ aim for intermediate mutation frequency 


\section{Recovery of mutant line for phenotyping}

- TILLING lines contain 100s-1000 or more induced point mutations, so the mutation of interest should be backcrossed to a non-mutagenized parental line (>2 generations)

- Mutant allele is followed using a genotyping method such as dCAPS

- If two different mutant alleles available, an allelism test can help associate mutation and an eventual nhenntype 


\section{Exploitation of TILLING via new genomics resources in Pea}

The Pea Gene Atlas http://bios.dijon.inra.fr/FATAL/cgi/pscam.cgi

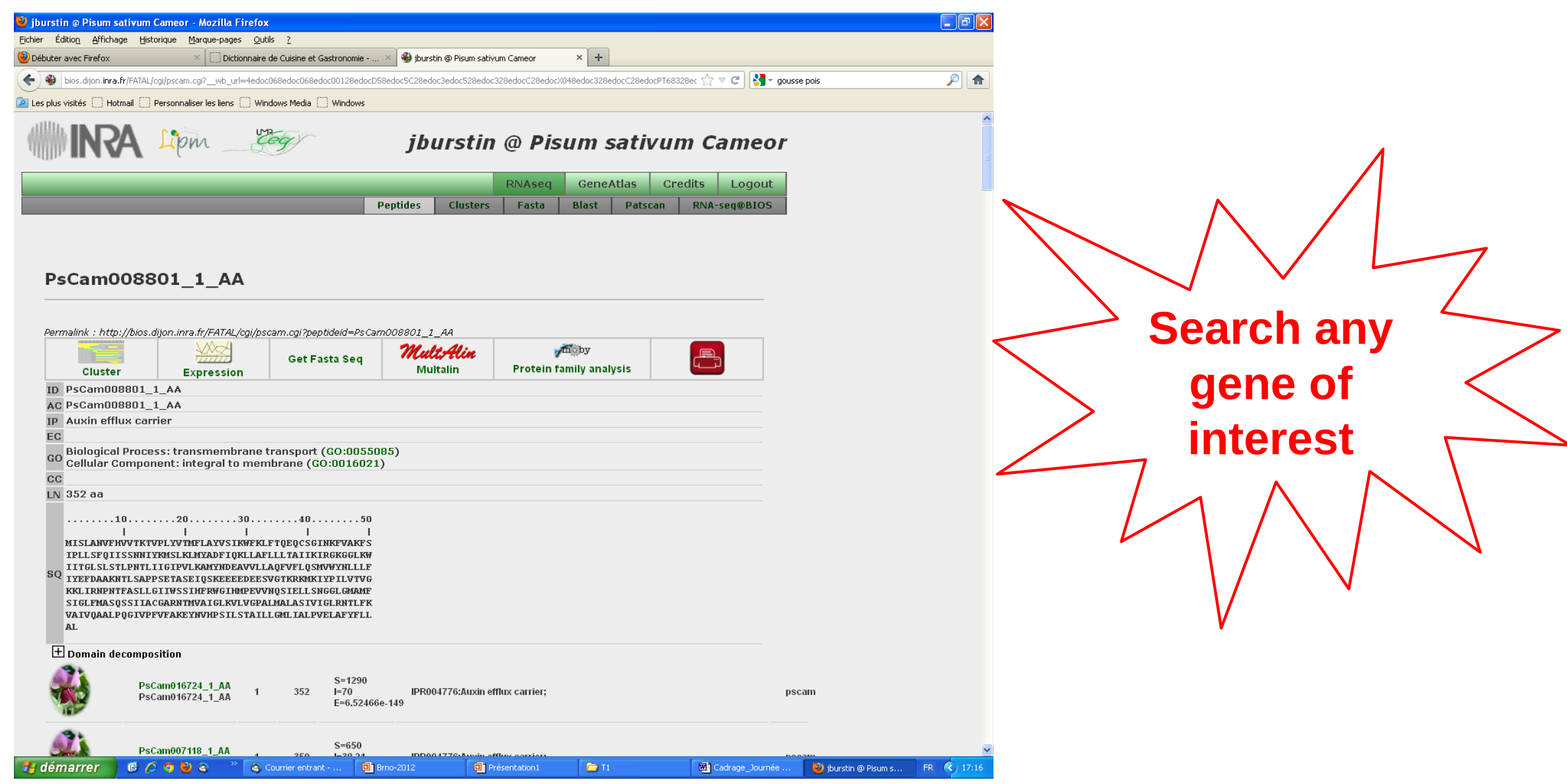




\section{Exploitation of TILLING via new genomics resources in Pea}

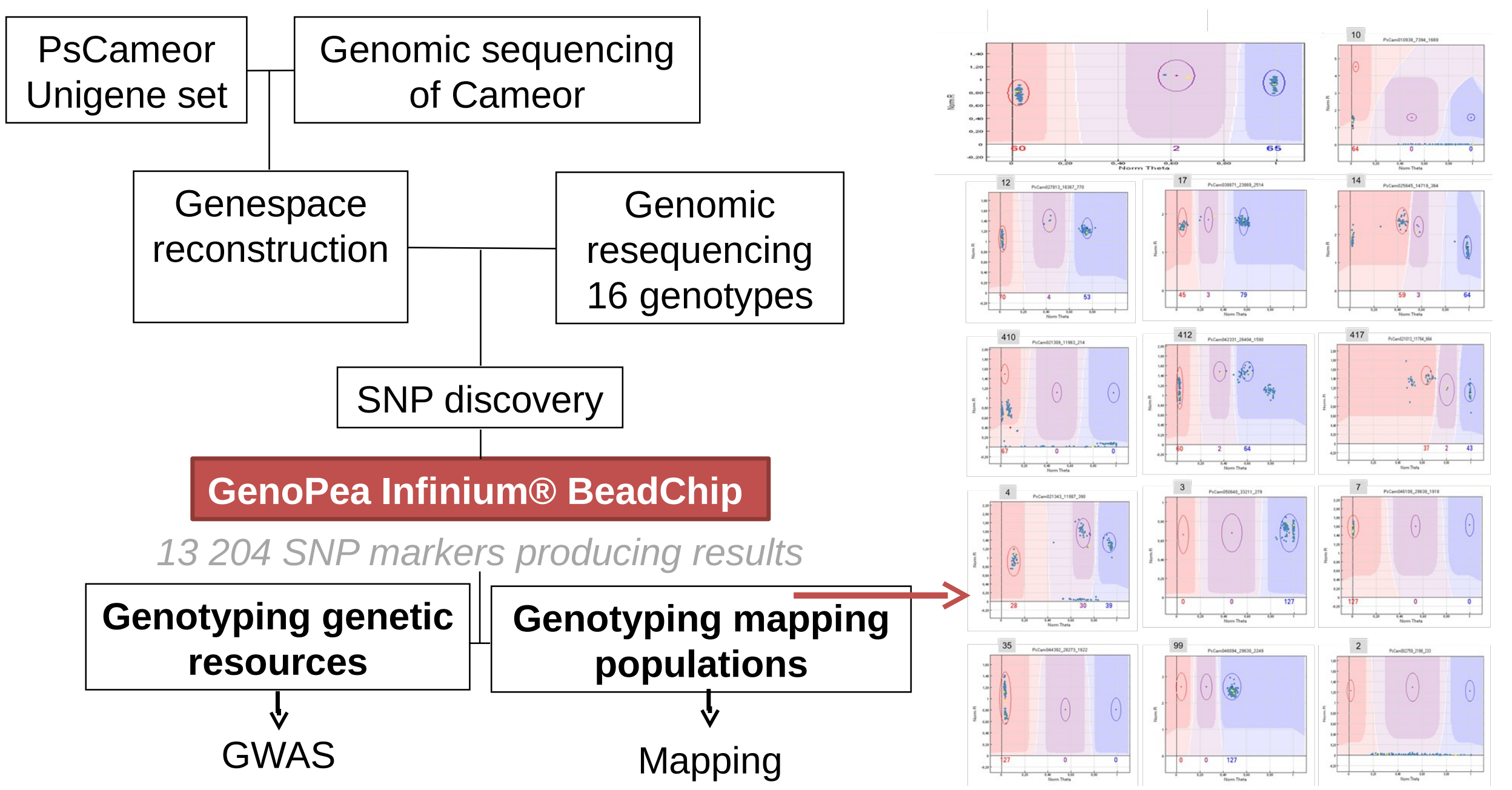

Aluome et al. submitted Tayeh et al. 2015, The Plant J. 


\section{TILLING: Widely used in Pea since 2008}

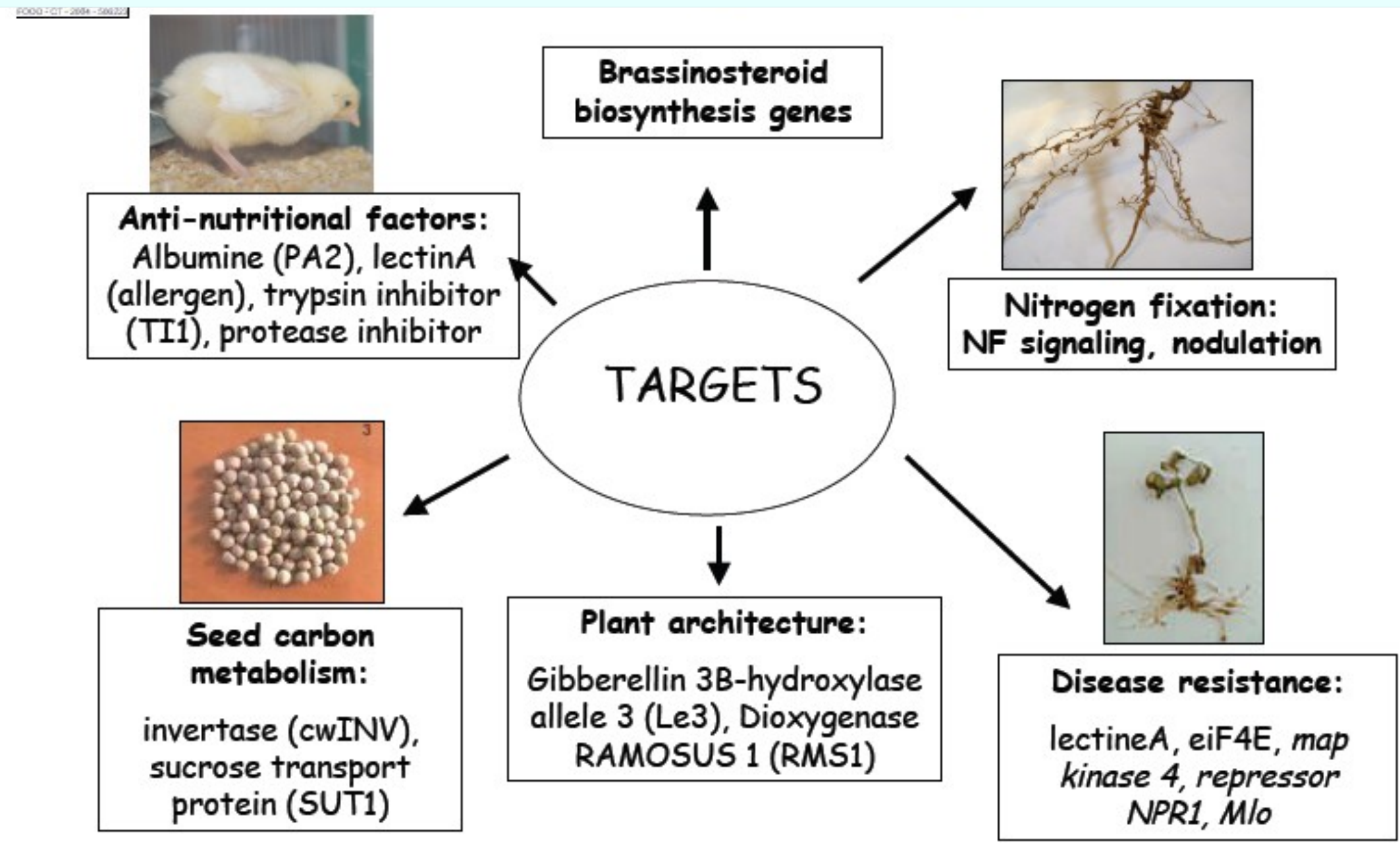




\section{Examples of TILLed genes in our project on seed development and composition}

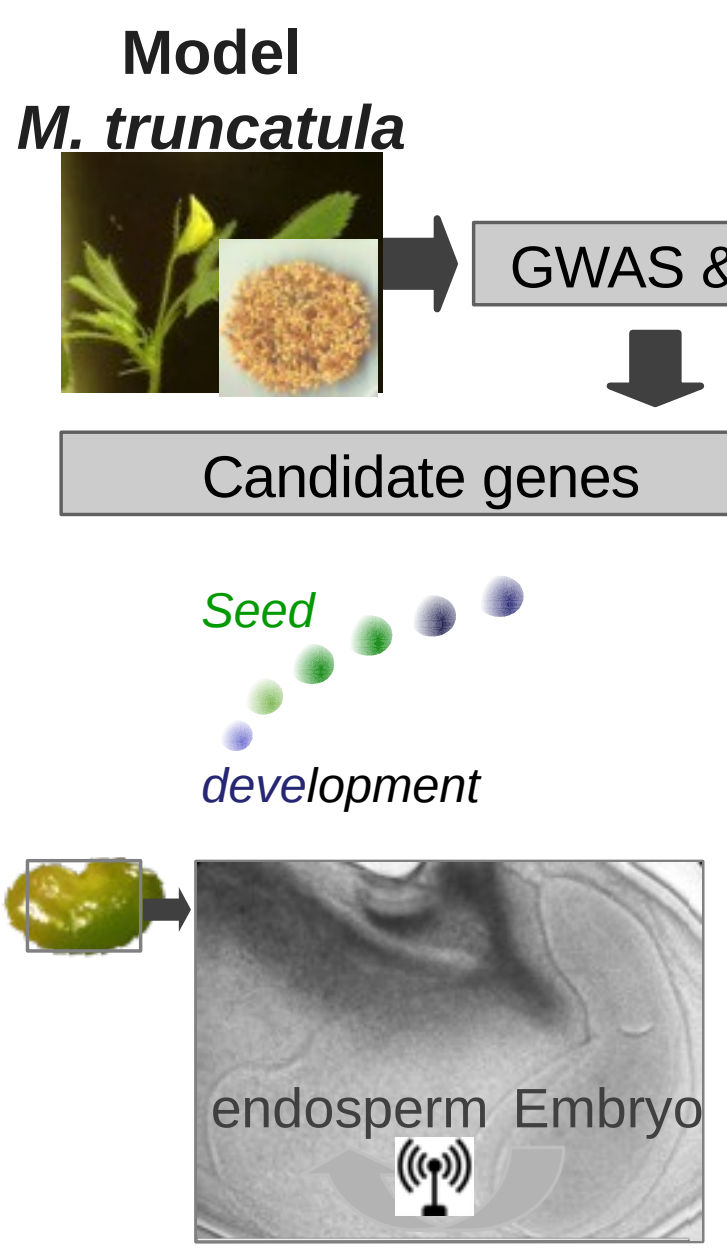

Communication \& intarartinn?
Crop

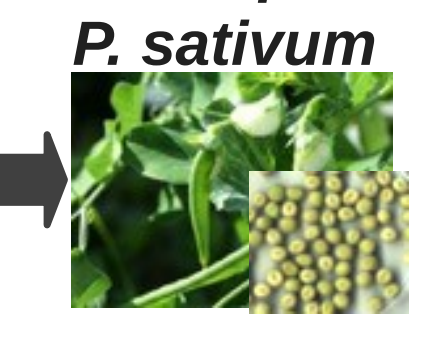

Putative pea orthologs 1-seed weight
Two genes with an endosperm-specific expression during embryogenesis determine final seed weight through the regulation of embryo cell division: a Subtilisin-like serine protea(((p))) Phytosulfokines ?
D'Erfurth et al., 2012 New Phytol.

- a DNA-binding with One zinc-Finger (DOF)-type transcription factor Noguero et al., 2013 Plant Sci. Noguero et al. 2015 Plant J.

Agroécologie 
A gene encoding a seed-specific subtilisin colocalizes with a Medicago seed weight QTL and is expressed at the interval embryogenesis-seed filling

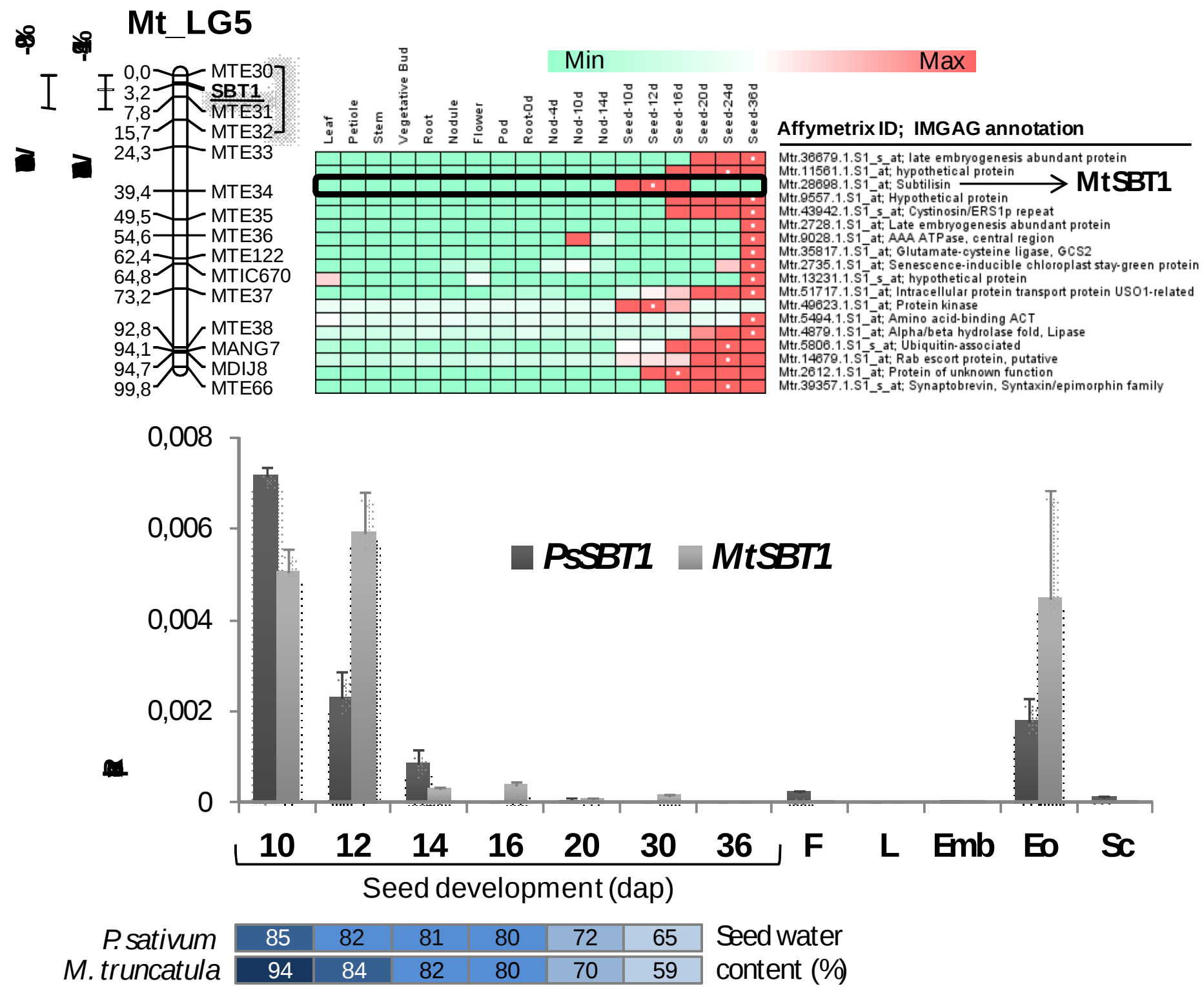


In situ hybridization of MtSBT1.1 to 10 and 12 DAP seeds

10 dap 12 dap

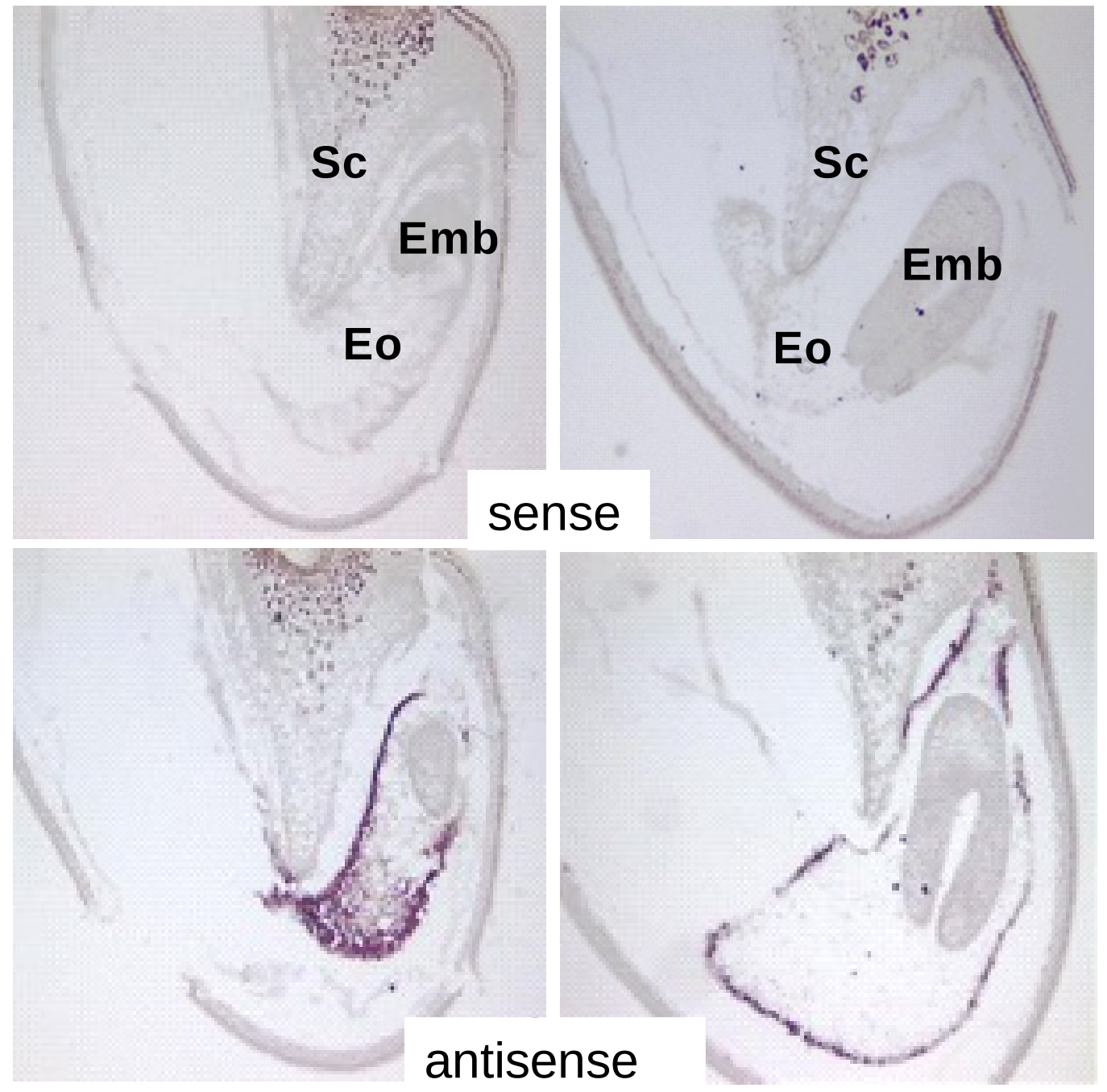




\section{Alignment of MtSBT1.1 AND PsSBT1.1 showing mutants available}

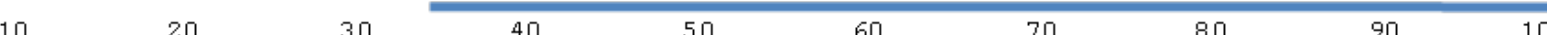

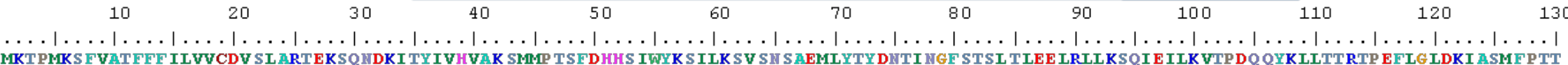

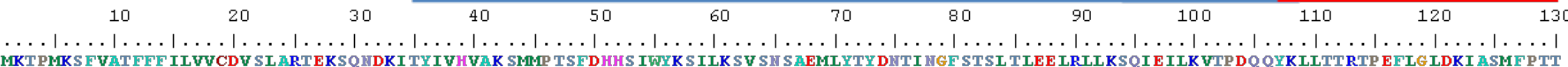

130

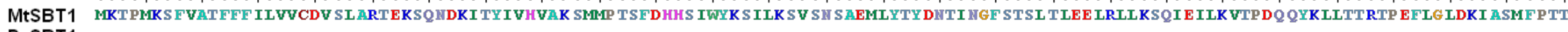

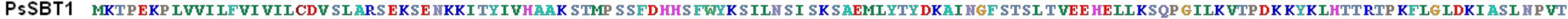

$$
\begin{array}{cc}
4 & 40 \mathrm{~W} \\
\text { MtR9 }
\end{array}
$$

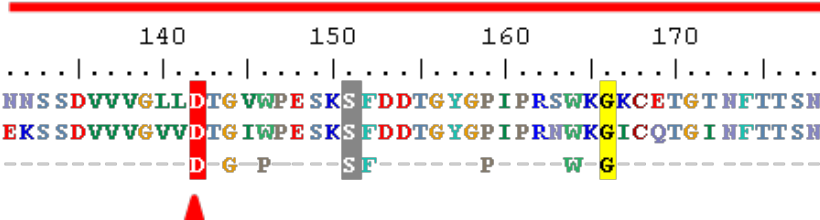

180

200

210

220

230

240

250

260

$\ldots|\ldots| \ldots|\ldots| \ldots|\ldots| \ldots|\ldots| \ldots|\ldots| \ldots|\ldots| \ldots|\ldots| \ldots|\ldots| \ldots|\ldots| \ldots|\ldots| \ldots|\ldots|$

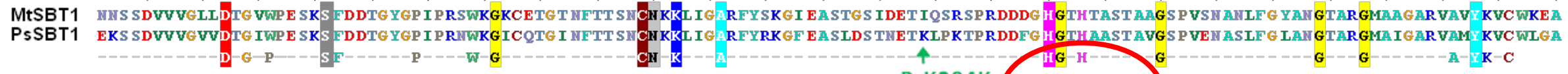

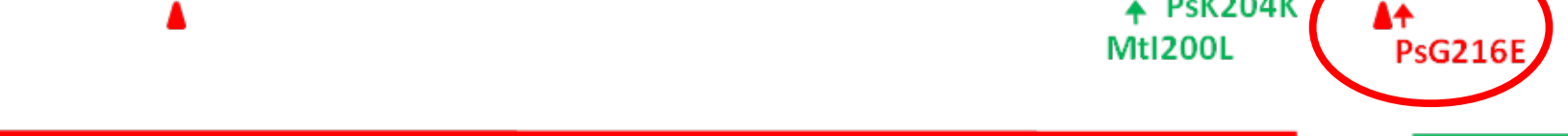

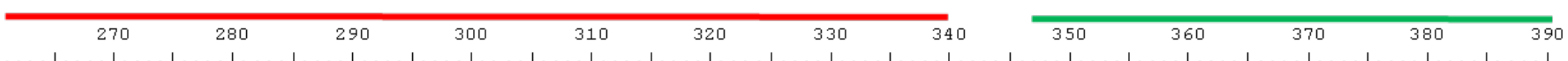

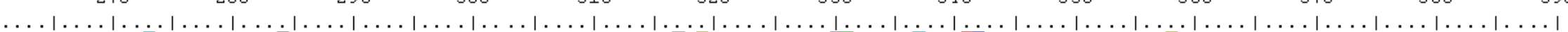

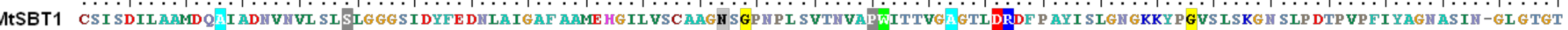

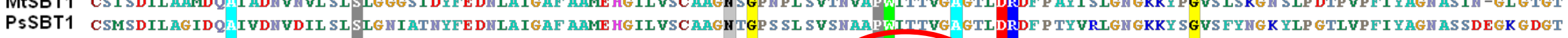

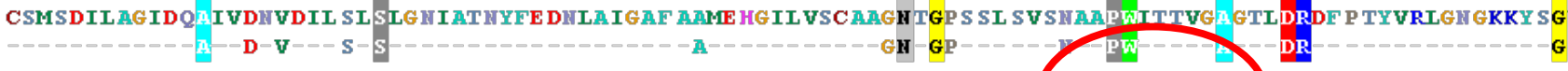

PsA314V

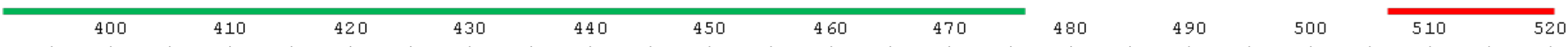

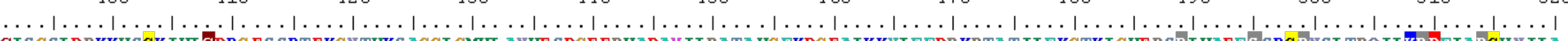

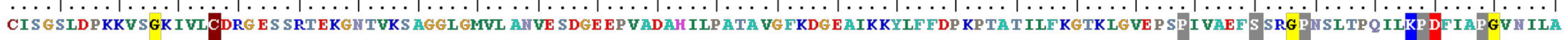

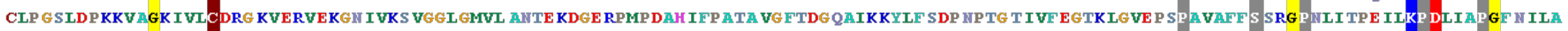

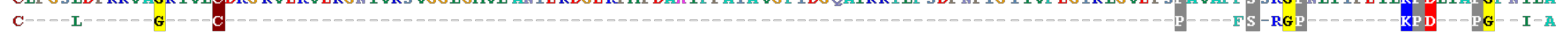

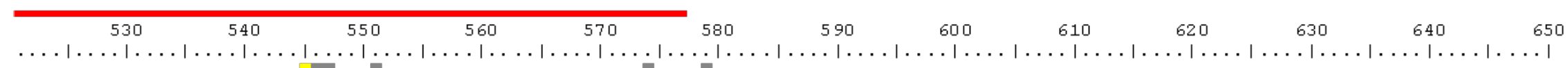

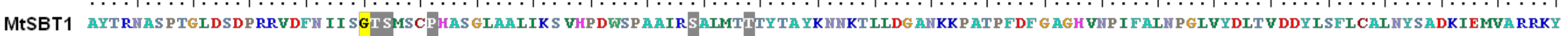

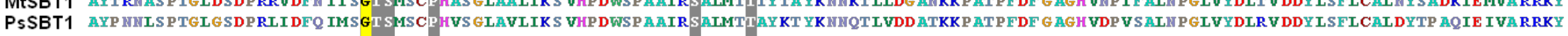
-
660
670
680
$690 \quad 700$
710
720
730
740
750
760

MTSBT1 TCDPKK

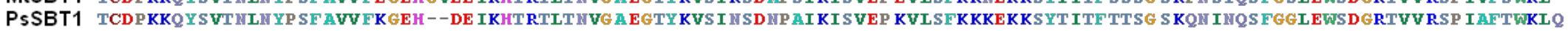

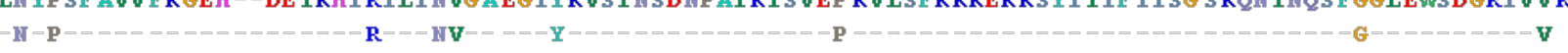




\section{Surface area and number of cotyledon cells in mature} seeds of the homozygous MtP330S mutant versus wildtype.
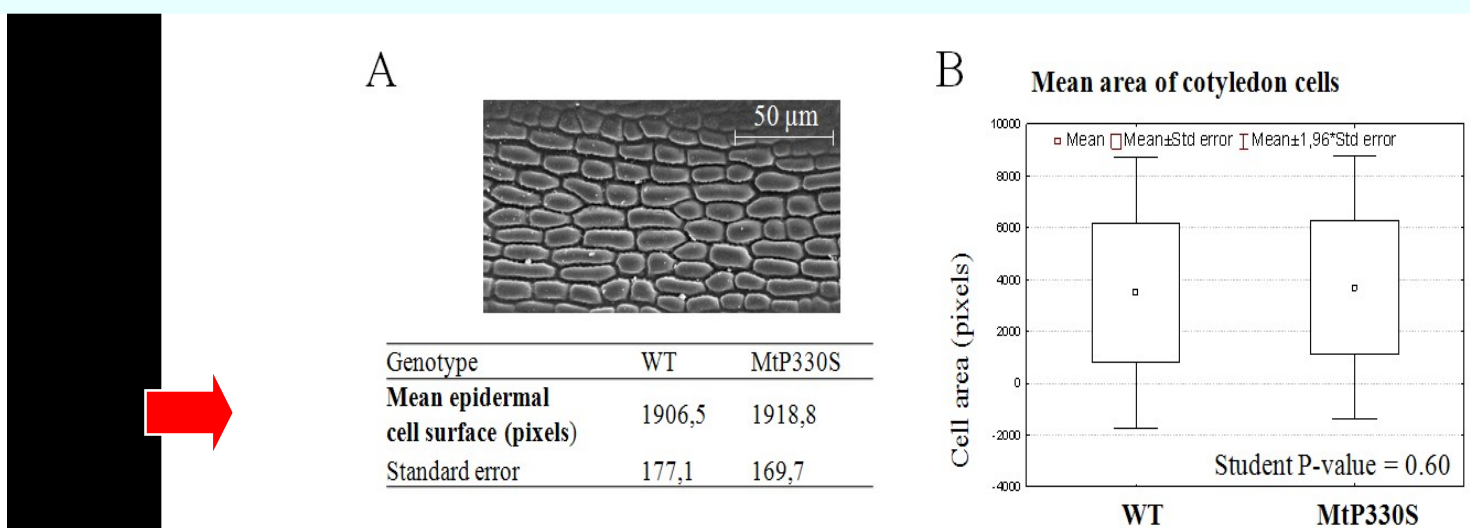

C

D Mean cotyledon cell number

Number of cells per 100000 pixels in 2 blocs
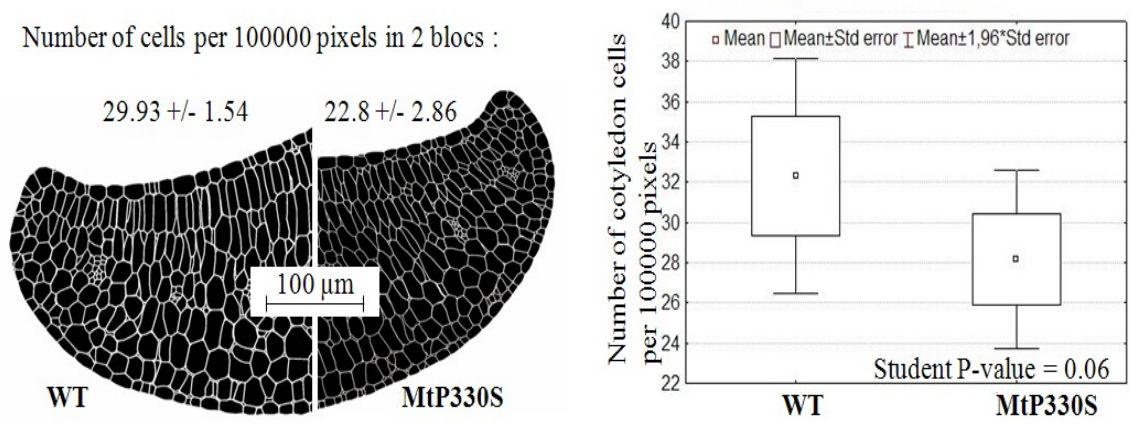


\section{Endosperm-specific genes controlling seed quality}

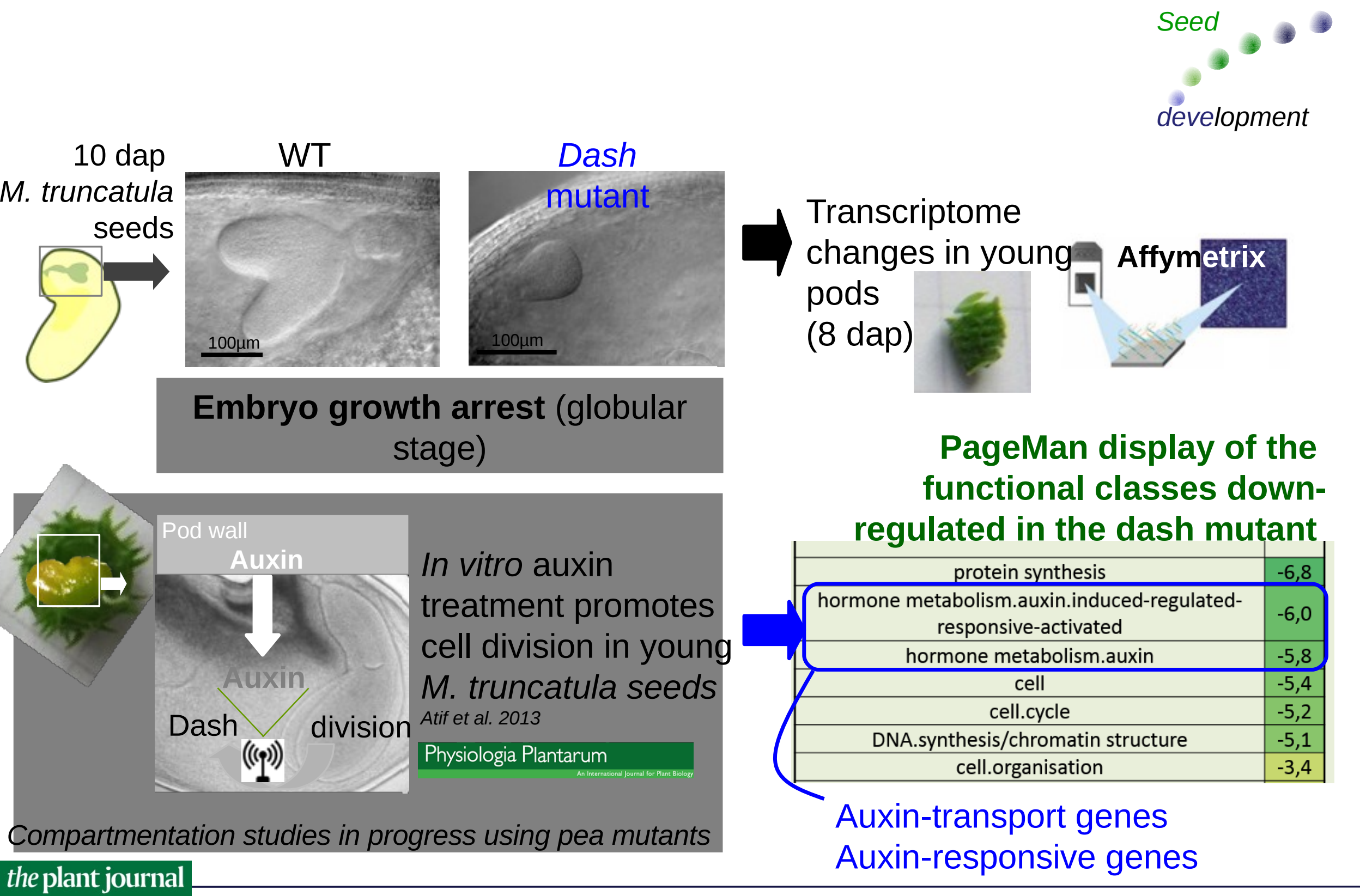




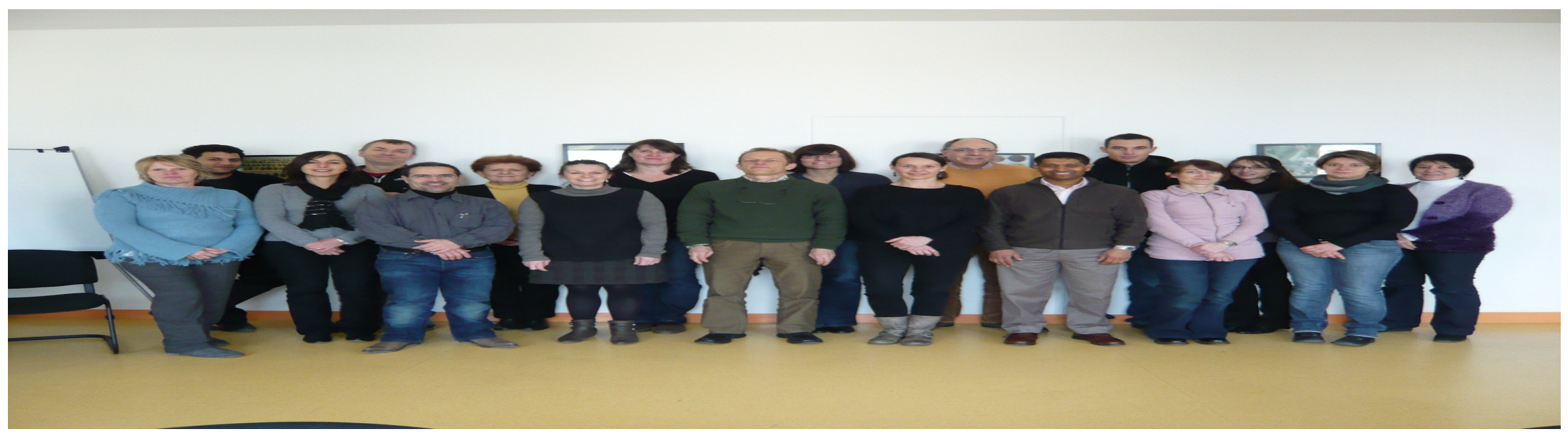

Melanie Noguero, Christine Lesignor, Brigitte Darchy, Greg Aubert, Myriam Sanchez, Judith Burstin, Karine Gallardo, (AE, Dijon) Jérôme Verdier (Shanghai Center for Plant Stress Biology)

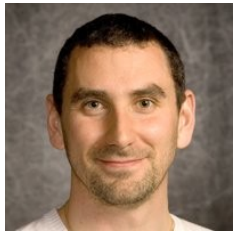

C. Saffray, M. Dalmais,

A. Bendahmane (IPS Saclay)
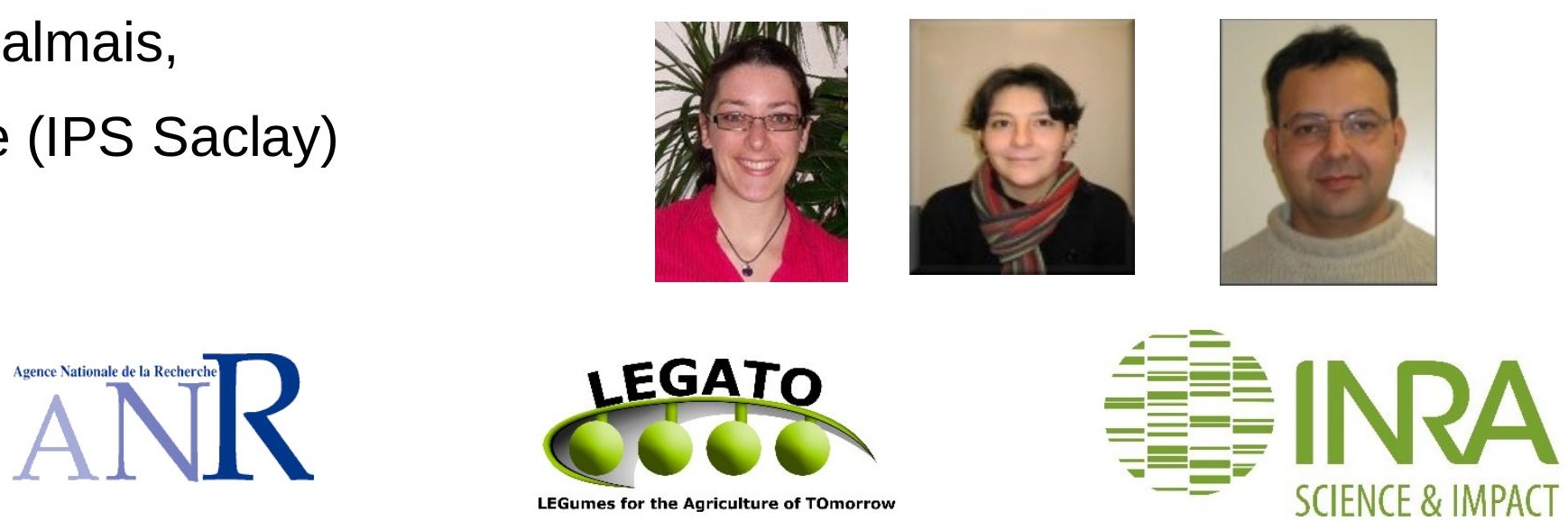



\section{Pea/Mtr TILLING: Publications arising}

\section{Resource development}

- Triques, K., et al. (2008). "Mutation detection using ENDO1: Application to disease diagnostics in humans and TILLING and Eco-TILLING in plants." BMC Molecular Biology 9.

- LeSignor C., (2009) Optimizing TILLING populations for reverse genetics in Medicago truncatula. Plant Biotechnology J. $7:$ :30-441

- Dalmais, M., UTILLdb, a Pisum sativum in silico forward and reverse genetics tool. Genome Biol. (2008) 9(2): R43.

\section{Examples of Applications}

Hofer, J., L. Turner, et al. (2009). "Tendril-less Regulates Tendril Formation in Pea Leaves." Plant Cell 21(2): 420-428.

Laura de Lorenzo, (2009) A Novel Plant Leucine-Rich Repeat Receptor Kinase Regulates the Response of Medicago truncatula Roots to Salt Stress The Plant Cell 21:668-680

Plet et al, (2011) MtCRE1-dependent cytokinin signaling integrates bacterial and plant cues to coordinate symbiotic nodule organogenesis in Medicago truncatula. Plant J. 65: 622-633.

Tivendale, N. D., S. E. Davidson, et al. (2012). "Biosynthesis of the Halogenated Auxin, 4Chloroindole-3-Acetic Acid." Plant Physiology 159(3): 1055-1063.

- D'Erfurth, I., C. Le Signor, et al. (2012). "A role for an endosperm-localized subtilase in the control of seed size in legumes." New Phytologist 196(3): 738-751.

- Noguero, M., C. Le Signor, et al. (2015). "DASH transcription factor impacts Medicago truncatula seed size by its action on embryo morphogenesis and auxin homeostasis." Plant Journal 81(3): 453-466.

Vernié, T, Camut S, et al (2016) PUB1 interacts with the receptor kinase DMI2 and negatively regulates rhizobial and arbuscular mycorrhizal symbioses through its ubiquitination activity in 